\title{
The Logical Validity of the Inquiry Based Learning Design of Plantae for High School Biology
}

1st Yasinta Choirina

\author{
Magister Program of Science \\ Education \\ Universitas Sebelas Maret \\ Surakarta, Indonesia \\ yasinta.choirina@gmail.com
}

2nd Murni Ramli

\author{
Departement of Biology Education \\ Universitas Sebelas Maret \\ Surakarta, Indonesia \\ mramlim@staff.uns.ac.id
}

\author{
3rd Yudi Rinanto \\ Departement of Biology Education \\ Universitas Sebelas Maret \\ Surakarta, Indonesia \\ yudi.rinanto@staff.uns.ac.id
}

\begin{abstract}
According to the preliminary survey involving 100 high school students in Surakarta City, Indonesia, students facing difficulties on classifying the Plantae, distinguishing the base determinants of plants classifying, and remembering the Latin nomenclature. To solve this problem, the new strategy of learning includes method and material has to be pursued. Inquiry-based learning is one of the most recommended approaches to learning science. This research aims to develop an inquiry-based learning design (IBLD) on Plantae, which combines three approaches, i.e. active learning, contextual, and scientific approaches, which is presumed to help students to understand the Kingdom of Plantae. This research followed the phases of DesignBased Research (DBR) to improve the current learning designs into the IBLD. To work with researchers, 35 biology teachers from 11 high schools and 4 university experts of biology education joined as research members. The logical validity had been applied by assessing the content and the build of the IBLD draft. The result shows that the draft is validated as excellent in all components, i.e. the design $(93 \%)$, content $(92 \%)$, method of teaching $(91 \%)$, assessment $(90 \%)$, and language $(92 \%)$. This result recommends to do testing the impact of the IBLD in the learning process by a series of multi-site test.
\end{abstract}

Keywords- Learning Design, Inquiry Learning, Plantae, Logical Validity, High School Biology

\section{INTRODUCTION}

Learning design depicts teaching and learning activities in the smallest learning unit (classrooms). The main principle of the learning design is the learning activities and the other supporting activities are done by teachers and students in learning [1]. The teachers must have and made their learning design designs to become guidance for teaching strategy in the classrooms. Learning design helps teachers to deliver the concepts to the students and helps students to understand the concepts better. But a lot of teachers meet difficulties to design their learning activities to match the educational target. Teachers also have difficulties to carry out their lesson plans because time constraints and students' unreadiness' to cope with changing learning methods. Students' readiness to cope with those changes affects their conceptual understanding. Learning design is one of the strategies to improve the quality of education because it guides the teachers to teach the matter so the students gain the best understandings.

Learning design differs from the lesson plan. Learning design is the process to design the lesson to help students study, meanwhile, the lesson plans is the process to develop and translate the school curriculum into the classroom learning activities [2]. Based on those statements, learning design is the design for the learning process to give the students more understanding about the concepts, including the learning goalsand desired outcomes. That also includes the strategy to obtain those goals, such as the methods, the techniques, the media, and assessment/evaluations.

This research is a Design-Based Research (DBR) adopted from Reeves [3]. DBR is a set of approach to obtain new theories, artifacts, and practices to explain impacts of learning in the class [4]. The DBR consisted of four phases: (1) Analysis of practical problems by researchers and practitioners in collaboration (preliminary), (2) Development of solutions informed by existing design principles and technological innovation (development phase); (3) Iterative cycles of testing and refinement of solutions in practice (testing phase); and (4) Reflection to produce "design principles" and enhance solution implementation (execution phase) [5].

In every DBR phase, collaborations and cooperation between the researchers, practitioners, and expert are involved from the start to the end and make the products in form of solutions toward the problem. The most challenging one is the start because need strong collaboration and cooperation between the researcher, practitioners, and experts. They must have active involvement in the research, especially to find out the root of the problem, and to find out the proper approach for solutions.

The research started with preliminary need assessment in eleven High School in Surakarta selected using purposive sampling. This preliminary 
step aimed to find out problems occurred in classrooms. The problems are scanned using direct observations, Pedagogical Content Knowledge (PCK) questionnaire, teachers' lesson plan analysis, textbook analysis, and conceptual understanding tests. The direct observations were made in several schools to find out the problems occurred in the classrooms. The results from observations are collected and after discussion with the teachers, we find out the teachers are meet difficulties to teach the concepts of the Plantae (Plant Biodiversity).

The Plantae is the basic concept to master by the student and become the basis to understand the next concepts learned. The Plantae taught at the tenth grade levels. Students have to master the basic concepts about the Plantae, so it is easy for them to understand about the Plant Structure (eleventh grade), and the Plant Genetics and Evolution (twelfth grade). Students who do not understand the basic concepts of the Plantae have difficulties to build further and more complex concepts. The results of the conceptual understanding test on Plantae from 372 students in eleven High School in Surakarta (February 2017) showed only $10.5 \%$ students have the comprehensive understanding, and the rest were not understood, or have misconceptions.

We also have the interview with students to find out their difficulties in learning about the Plantae, especially about the plants' classifications, characteristics, scientific names, and differing certain plant groups. From the interview we find out the students have difficulties to state the plants' classifications, characteristics, scientific names, differing certain plant groups, explain the plants' body structures, plants reproduction methods, and plant roles in the life [6]. They also have difficulties to made plant classification with the scientific names [7]. Students' difficulties in learning about the Plantae can be overcome using meaningful learning [8].

Students' conceptual understanding is very important in education practices. The deeper students' understanding, the better their memory retention and means they got meaningful learning [9]. Conceptual understanding must be embedded into students through direct interactions with the objects or phenomena related to the concepts [10]. Incomplete understand resulted in students' misconceptions. If students have misconceptions, it would be difficult to be corrected [11].

Misconceptions because of misunderstanding or incomplete understanding can be prevented using the learning strategy that complies with current educational targets. The teacher must change their learning design to motivate and impress the students to learn. Changes in the lesson design imply changes in learning models, such as the use of questions oriented learning to drive students' curiosity and motivate the students to explore and find out the answer to their curiosity. Those processes are the inquiry. The processes to ask the questions, find out the knowledge or information, observe the phenomena, and find out the answer or concepts with students' active involvement [12].

The processes of the inquiry involving the students in a lot of questioning and thinking activities to build new concepts [13]. In the inquiry, students act as if they are the scientist, to find out the knowledge, confirming the knowledge, or find out the right answer to their questions [14]. In the inquiry process, the students have opportunities to interact with the object around them so the learning process will be more meaningful, and they will gain more understanding.

Difficulties in the learning process not only encountered by students but also by teachers. Based on PCK survey from 22 biology teachers (December 2016), we found out teachers have difficulties to construct their lesson plan, applying the inquiry learning, and serving the facts and phenomena related to the concepts to students. Those difficulties are urgent to be solved because related to students' understanding. If the teacher can make students understand the concepts of the Plantae, the learning process in fail or not optimal.

Based on the elaborated problems, we need a strategy to improve learning in classrooms. One of the solutions is to make learning design that helps teachers deliver the concepts of the Plantae with ease and make students understand better. The proper learning design is the Inquiry-Based Learning Design (IBLD), the learning design involve the students to explore and find out the concepts of the Plantae, and so they can have meaningful learning. Meaningful learning resulted in better understanding and can ease students to understand the concepts. IBLD on the Plantae is the attempt to deliver the concepts of Plantae to the students. Through IBLD, students will gain more understanding and help teachers to build teaching habit with inquiry-based learning.

This research aimed to build the Inquiry-Based Learning Design for the Plantae and find out the logical validity of the constructed draft. The research questions were: (1) what are the characteristics of the IBLD for Plantae to anticipate the misconceptions? (2) How about the logical validity of the IBLD for Plantae?

\section{METHODS}

This was a research and development applying the Design-Based Research (DBR) approach. The DBR consisted of four phases: (1) Analysis of practical problems by researchers and practitioners in collaboration (preliminary), (2) Development of solutions informed by existing design principles and technological innovation (development phase); (3) Iterative cycles of testing and refinement of solutions in practice (testing phase); and (4) Reflection to produce "design principles" and enhance solution implementation (execution phase) [5]. 


\section{A. Phase 1, Analysis of practical problems by researchers and practitioners in collaboration}

Phase one started by finding out the problem occurred in learning the Kingdom of Plantae in high school in Surakarta. Thirty-five Biology teachers and 100 students were interviewed to scan out the problems on studying the Kingdom of Pantae. There were some problems stated by teachers and students, and it was mostly tend to the difficulties of students on understanding the basis of classification in the Kingdom of Plantae. It was also found that teachers commonly taught the Plantae by expository and based on the textbook. The inquiry activities were not common, and teachers do not have adequate knowledge to do student-centered and inquiry-based activities.

To detect the understandings of students about the concepts of Plantae, a paper test was done for 372 students selected randomly from 11 high schools in Surakarta city. The result showed that only $10.5 \%$ of students understand comprehensively the concepts of Plantae. The rest students were categorized as not understand or misconception.

\section{B. Phase 2, Development of solutions informed by existing design principles and technological innovation}

The problem of students and teachers as well in learning the Kingdom of Plantae needs to be addressed as soon as possible. Some solutions, such as revising the misconceptions in the textbook, applying the contextual learning activities, students-based activities, and inquiry learning has suggested by the research members. After analysing the possibilities, the research team decided to improving the learning strategy of Plantae by developing the inquiry based learning design (IBLD) for Plantae.

The IBLD proposed as the potential solution to help the teacher optimize learning in the classroom helps the teacher to deliver the concepts and help the students to build conceptual understanding about the Plantae. The IBLD proposed as the solution because teachers need proper learning design for the topic of Plantae.

\section{Phase 3 Iterative cycles of testing and refinement of solutions in practice}

The learning design then improved and refined gradually. Collaborations between the researchers, practitioners, and experts were crucial to improve the IBLD. The improvement process conducted by workshops with the practitioner and experts. The workshops were held three times. Three biology teachers act as the practitioners, and two lecturers were acted as the experts.

The first workshop (12 February 2017) was to define the focus of solution of the problems. The second workshop (12 March 2017) was to build the IBLD. The third workshop (26 March 2017) was to revise and refine the IBLD. The second and the third workshops were the Phase 2 of this research. The third phase was to validate the IBLD. The IBLD was validated by 35 biology teachers in Surakarta. The revisions and improvements have done continuously. In this research, we stop at the Third Phase because of time constraints to have the perfect design.

\section{Phase 4 Reflections to produce "design} principles" and enhance solution implementation

The IBLD still have to be improved because have a lot of weakness and faults. Further multisite testing were required to validate the IBLD. We skip this phase because of time constrain.

\section{RESULTS AND DISCUSSION}

\section{A. Description of the Inquiry Based Learning Design on the Topic of the Plantae}

The IBLD on the Plantae covers the characteristics, reproductions, classifications, and the roles of the Plant. The concepts covered in the IBDL were constructed based on the six steps of the inquiry [15]: observe, formulate inquiry questions, develop hypothesis, design and conduct investigation, analyze data, and argue. Those six steps constructed sequentially every lesson time. Every lesson time consisted of three learning periods $(3 \times 45$ minutes $)$ covering one sub-chapter of the Plantae. The IBLD of the Plantae consisted of five lesson times covering five different sub-chapters. The chapters sequence can be seen in Table I. The learning activities were contextualized and accompanied by plant samples and specimens to counter students' misconceptions.

The main characteristics of the plants were covered in the first meeting. The students were asked to identify the similarities and differences between the sample of the plants and plant-like organisms. They then asked to classify the sample and analyze the classification. The students are expected to understand the basic characteristic that differs the plant from the plant-like-protists. At the second meeting, the students were asked to identify the mosses and determine the differences based on the observed characteristics. The students were expected to find out the classification basis for mosses in classes and orders levels, and what differs mosses with higher plant phyla. Moss reproductions delivered learned from the analysis of sketch about moss reproductions. Moss roles in life learned by using literature study.

TABLE I. SUB-CHAPTER SEQUENCES AND THE MEDIA FOR EACH MEETING

\begin{tabular}{|c|c|c|c|}
\hline Meeting & Topics & Descriptions & The samples \\
\hline I & $\begin{array}{l}\text { Plants' General } \\
\text { Characteristics }\end{array}$ & $\begin{array}{l}\text { Plants' general } \\
\text { characteristics, } \\
\text { what differs } \\
\text { the plants from } \\
\text { plant-like } \\
\text { organisms, } \\
\text { how to classify } \\
\text { the plant. }\end{array}$ & $\begin{array}{l}\text { Seaweed, } \\
\text { hornworts, } \\
\text { Equisetums, } \\
\text { elephant grass, } \\
\text { and cactus. }\end{array}$ \\
\hline II & The Moss & Characteristics, & Liverworts, \\
\hline
\end{tabular}




\begin{tabular}{|c|c|c|c|}
\hline Meeting & Topics & Descriptions & The samples \\
\hline & (Bryophyta) & $\begin{array}{l}\text { classification, } \\
\text { reproductions, } \\
\text { and roles of the } \\
\text { moss. }\end{array}$ & $\begin{array}{l}\text { Hornworts, and } \\
\text { Musci/ } \\
\text { Bryopsids. }\end{array}$ \\
\hline III & $\begin{array}{l}\text { The Ferns } \\
\text { (Pteridophyta) }\end{array}$ & $\begin{array}{l}\text { Characteristics, } \\
\text { classification, } \\
\text { reproductions, } \\
\text { and roles of the } \\
\text { ferns. }\end{array}$ & $\begin{array}{l}\text { Psilotopsids, } \\
\text { Lycopodiopsids, } \\
\text { Equisetums, and } \\
\text { Pteropods. }\end{array}$ \\
\hline IV & $\begin{array}{l}\text { The } \\
\text { Gymnosperms } \\
\text { (Gymnospermae) }\end{array}$ & $\begin{array}{l}\text { Characteristics, } \\
\text { classification, } \\
\text { reproductions, } \\
\text { and roles of the } \\
\text { Gymnosperms. }\end{array}$ & $\begin{array}{l}\text { Various } \\
\text { Gymnosperms. }\end{array}$ \\
\hline V & $\begin{array}{l}\text { The } \\
\text { Angiosperms } \\
\text { (Angiospermae) }\end{array}$ & $\begin{array}{l}\text { Characteristics, } \\
\text { classification, } \\
\text { reproductions, } \\
\text { and roles of the } \\
\text { Angiosperms, } \\
\text { how to differ } \\
\text { monocots and } \\
\text { dicots. }\end{array}$ & $\begin{array}{l}\text { Berbagai jenis } \\
\text { tumbuhan } \\
\text { monokotil dan } \\
\text { dikotil. }\end{array}$ \\
\hline
\end{tabular}

At the third meeting, the students form group investigations. Each group was asked to bring samples of ferns. And each of the group was asked to identify the ferns collected. The students were expected to find basic characteristics among the ferns orders and classes. Students were expected to understand what the main character differs the ferns from other plants. The reproduction of the ferns studied using the graphical scheme, and the students were asked to analyze the process. The role of the ferns studied using literature study. At the fourth meeting, students were asked to bring samples of the gymnosperms and asked to find the characteristics, classifications, reproductions, and roles of the gymnosperms. Students then ten compared their works with others.' At the fifth meeting students faced with the dicots and the monocots. They were asked to analyze the differences between the two groups and assign each of the samples on the proper groups.

Those sub-chapters were constructed based on the sequence from the most basic to the most complex, so students can understand easily. The most basic concepts taught first to prepare the students, to decrease the misconceptions, to recall students' memory, and become the basis for learning more complex concepts.

TABLE II. RESUlt OF THE TEST OF StUdENTS' CONCEPTUAL UNDERSTANDING ABOUT THE PLANT

\begin{tabular}{|l|c|l|}
\hline \multicolumn{1}{|c|}{$\begin{array}{c}\text { Categories for Students' } \\
\text { Conceptual Understanding }\end{array}$} & $\begin{array}{c}\text { Percentage } \\
(\boldsymbol{\%})\end{array}$ & \multicolumn{1}{|c|}{ Concepts } \\
\hline Fully Understand & 11 & $\begin{array}{l}\text { Plants' General } \\
\text { Characteristics }\end{array}$ \\
\hline $\begin{array}{l}\text { Not Understand/Partially } \\
\text { Understand }\end{array}$ & 50 & $\begin{array}{l}\text { The } \\
\text { Angiosperms }\end{array}$ \\
\hline Misconception & 39 & $\begin{array}{l}\text { The } \\
\text { Angiosperms }\end{array}$ \\
\hline
\end{tabular}

Students' understanding became the basis to develop the IBLD. Paper-based tests and interviews were conducted before developing the IBLD, to find out how far students understand the concepts. Students' difficulties also showed through the test and interviews, so we can think the proper solution in IBLD to overcome those difficulties (Table II).

The result of the test of students' conceptual understanding about the plant from 372 high school students showed the students who understand the concepts were fewer than the students with no/partial understanding and the students with misconceptions. Based on the interview with students, the students tend to have misconceptions and not understood the concepts of the Plantae. Those especially in the Angiosperms sub-chapter, when students were asked to classify the Angiosperms into dicots and monocots. To counter students' partial understanding and misconceptions, the IBLD on the Plantae, students were trained to understand the characteristic of the Angiosperms, and how to classify the dicots and monocots. Students have direct interactions with the dicots and monocots plants and find the differences between those two groups. Because students do it by themselves, the inquiry process was happening, and students were expected to understand the concepts better because they have direct experience and meaningful learning. Teachers played roles to help and direct the students when meet difficulties in confirmation stage.

TABLE III. LEVELS OF THE INQUIRY BASED LEARNING FOR PLANTS

\begin{tabular}{|c|c|c|c|c|}
\hline $\begin{array}{c}\text { Sub- } \\
\text { chapters }\end{array}$ & $\begin{array}{l}\text { Levels of } \\
\text { Inquiry }\end{array}$ & Problem & $\begin{array}{c}\text { Procedu } \\
\text { res }\end{array}$ & Solutions \\
\hline & $\begin{array}{l}\text { Level } 0 \text {, } \\
\text { Confirma } \\
\text { tion }\end{array}$ & Teacher & Teacher & Teacher \\
\hline $\begin{array}{c}\text { Plants' } \\
\text { General } \\
\text { Characteristi } \\
\text { cs }\end{array}$ & $\begin{array}{l}\text { Level 1, } \\
\text { Structure } \\
\text { d Inquiry }\end{array}$ & Teacher & Teacher & Students \\
\hline $\begin{array}{c}\text { Characteristi } \\
\text { cs, } \\
\text { classification, } \\
\text { reproductions } \\
\text {, and roles of } \\
\text { the moss. } \\
\text { (Bryophyta), } \\
\text { the ferns } \\
(\text { Pteridophyt } \\
\text { a), and the } \\
\text { Gymnosperm } \\
\text { s. }\end{array}$ & $\begin{array}{l}\text { Level 2, } \\
\text { Guided } \\
\text { Inquiry }\end{array}$ & Teacher & Students & Students \\
\hline $\begin{array}{l}\text { Characteristi } \\
\text { cs, } \\
\text { classification, } \\
\text { reproductions } \\
\text {, and roles of } \\
\text { the } \\
\text { Angiosperms } \\
\text { (monocots } \\
\text { and dicots) }\end{array}$ & $\begin{array}{l}\text { Level 3, } \\
\text { Open } \\
\text { Inquiry }\end{array}$ & Students & Students & Students \\
\hline
\end{tabular}

The IBLD built based on the four levels of the inquiry from [16]: level 0 (confirmation), level 1 (structured inquiry), level 2 (guided inquiry), and level 3 (open inquiry) (Table III). The IBLD on the Plantae only uses three highest inquiry levels: the structured 
inquiry, the guided inquiry, and yhe open inquiry. Level 0 (confirmation) not used because unsuitable for high school students. At confirmation inquiry, teachers have full control in defining the problem, designing the procedure, and find out the solution, thus students' activities were limited. Meanwhile, high school students are expected able to study independently.

Every level of inquiries has different purposes and characteristics. Confirmation aimed to confirm or proof the concepts by experiment activities. Each component has defined strictly by the teacher. Structured inquiry aimed to find out the solution to the problem proposed by the teacher, with the procedure have defined by the teacher, to give students opportunity to carry out experiments or investigation. Guided inquiry aimed to define the procedure and solution for the problems proposed by teachers. Open inquiry requires scientific thinking and high competencies because students were asked to investigate the problems related to their topic choices, using their own methods. In the open inquiry, students can act as if they were scientists; ask the questions, designing and doing experiments, and communicate the results.

\section{B. Construction of the Inquiry Based Learning Design (IBLD)}

The IBLD constructed sequentially, with three workshops and draft validations. Workshops were held to discuss the content of the IBLD. Every end of the workshop, the revisions of the earlier discussion were made. The next workshop discuss the development of the IBLD based on the earlier revisions.

The first workshop defined the frameworks for the IBLD: (1) the topics; (2) time allocations; (3) core competencies; (4) basic competencies; (5) learning indicators, and (6) learning materials. It then suggested adding more topics so each meeting correspondents to the sub-chapters. The chapters were designed using triangle consisted of the goals, methods, and assessments. Chapter design was presented in the second workshop. The time allocations revised into six time-allocations with the number of indicators fitted with the indicators for each sub-chapter. The sub-chapters were: the plants' general characteristics, the moss, the ferns, the gymnosperms and the angiosperms, differences of the dicots and monocots, and roles of plants in the life.

The second workshop discussed the chapter design triangle from the first workshop. The experts and practitioners asked to reduce the meeting to only five meetings with five sub-chapters (Table 3 ) and revised the chapter design triangle by adding the matters and the media to become the four fundamental components in the IBLD. The experts said the triangle chapter design was unsuitable for Indonesian school because too simple and less detailed. The IBLD draft must also be equipped with the lesson plan for further detail and easy to understand.
The third workshop discussed the revisions of the IBLD from the second workshop. The IBLD have complimented with the lesson plan consisted of four components: the goals, matters, and the media, methods, assessment. Based on the discussions, the matters were inseparable with other components. Because when learning occurred, teachers must deliver concepts about the certain matter or topic. Media used in the IBLD primarily life samples, both partial specimens and whole parts of plants. If the real samples were hard to find, photos or videos are permitted. The IBD from the third workshop still needs to be revised to be detailed draft ready for validations.

After the workshops, the IBLD draft further developed to further explain the contents. The main contents of IBLD were: (1) learning design, (2) important principles to develop the learning design, (3) basic principles to teach about the Plantae and (4) lesson plan for the topic of Plantae. The first point was the introduction to the learning design. The second was about the principles must be obeyed to develop learning design. The third was about the basic concepts of the Plantae; with facts about students' basic understanding; principles to teach about the Plantae using the inquiry, contextual, and active learning approaches; and good assessment system for the topic of the Plantae. The fourth point was about the lesson plan about the Plantae with learning scenario, the rubric for assessment, sample questions, and students' worksheets.

The IBLD then validated by the practitioner (35 high school biology teachers), one expert on language, two experts on the subject matter, and one expert on learning design. The results of validations shown in Table IV. The validations were the third phase of the research to get the proper learning design.

TABLE IV. RECAPITULATION OF THE RESULTS OF VALIDATIONS

\begin{tabular}{|c|c|c|c|}
\hline $\begin{array}{c}\text { The } \\
\text { Components }\end{array}$ & $\begin{array}{c}\text { Percentage } \\
(\%)\end{array}$ & Category & $\begin{array}{l}\text { Validation } \\
\text { Notes }\end{array}$ \\
\hline $\begin{array}{l}\text { Leaning } \\
\text { design }\end{array}$ & 86 & Very good & $\begin{array}{l}\text { Need } \\
\text { explanation } \\
\text { for teachers to } \\
\text { differentiate } \\
\text { the learning } \\
\text { method and } \\
\text { the learning } \\
\text { strategy. }\end{array}$ \\
\hline Topic/matter & 88 & Very good & $\begin{array}{l}\text { The content } \\
\text { matter } \\
\text { complimented } \\
\text { with the latest } \\
\text { research } \\
\text { journals. }\end{array}$ \\
\hline Method & 89 & Very good & $\begin{array}{l}\text { In observe } \\
\text { stage, it is } \\
\text { better to bring } \\
\text { life samples } \\
\text { than photos or } \\
\text { videos if the } \\
\text { samples are } \\
\text { easy to find. }\end{array}$ \\
\hline Assessment & 86 & Very good & The \\
\hline
\end{tabular}




\begin{tabular}{|c|l|l|l|}
\hline & & & $\begin{array}{l}\text { assessment } \\
\text { tool quite } \\
\text { good, but } \\
\text { maybe } \\
\text { teachers have } \\
\text { some } \\
\text { difficulties to } \\
\text { implement, } \\
\text { find out the } \\
\text { solutions. }\end{array}$ \\
\hline $\begin{array}{c}\text { Language } \\
\text { usage }\end{array}$ & 87 & Very good & $\begin{array}{l}\text { Some } \\
\text { mistypes are } \\
\text { found. }\end{array}$ \\
\hline
\end{tabular}

a. The percentages have converted from the average score of 35 teachers and 4 experts.

Based on Table IV, the IBLD on the Plantae was very good in the component of learning design, matter or topics, assessment method, and language usage, but must be revised and refined before usage. Few notes from the validators can be used to improve the IBLD. The multisite tests must be conducted to ensure the validity and impacts of the IBLD.

\section{CONCLUSION}

The IBLD was built using the principles of the active learning, cooperative learning, inquiry learning, and contextual learning, with four components; matter or topics; the goals; the methods, and the assessments. The IBLD adopted six steps of the inquiry. The logical validity of the IBLD drafted in this research shows that this IBLD is valid, and potentially to be applied as a learning design in teaching and learning the Kingdom of Plantae. To check the impact of this IBLD to the students understanding on the concepts of Plantae, a series of multisite test is proposed.

\section{ACKNOWLEDGMENT}

This research was funded by Grant for Postgraduate Research at Universitas Sebelas Maret in 2017. The team was led by Murni Ramli.

\section{REFERENCES}

[1] R. Koper, "Current Research in Learning Design," Educational Technology \& Society, vol. 9, pp. 13-22, 2006.

[2] S. G. Magliaro \& N. Shambaugh, "Teachers' Personal Models of Instructional Design," Advances in Research on Teaching, vol. 11, pp. 101-134, 2005.

[3] T. C. Reeves, "Design Research from a Technology Perspective," Educational Design Research, pp. 64-78, 2006.

[4] S. Barab \& K. Squire, "Design-Based Research: Putting a Stake in the Ground," Journal of the Learning Sciences, vol. 13, pp. 1-14, 2004.

[5] J. Herrington, S. McKenney, T. C. Reeves, \& R. Oliver, "Design-based Research and Doctoral Students: Guidlines for Preparing a Dissertation Proposal,” ECU Publications, 2011.
[6] U. Zarisma, M. Qurbaniah, \& N. D. Muldayanti,. "Identifikasi Kesulitan Belajar Siswa pada Materi Dunia Tumbuhan Kelas X SMA Negeri 1 Sambas," Journal Biology Education, vol. 3, pp. 33-41, 2016.

[7] P. Marisa, R. Lestari, \& R. Karno, "Analisis Kesulitan Belajar Siswa pada Materi Tumbuhan Kelas X di SMAN 1 Rambah Hilir Tahun Pembelajaran 2014/2015," e-journal UPP, pp. 15, 2015.

[8] Armi \& A. Noviyanti, "Aktivitas Siswa pada Pembelajaran Plantae Berbasis Keterampilan Proses Sains di Kelas X SMAN Aceh Besar," Prosiding: Seminar Nasional dalam Rangka Konsorsium Perguruan Tinggi Indonesia Pittsburgh "Optimalisasi Pelaksanaan Kurikulum 2013, Banda Aceh: Fakultas Keguruan dan Ilmu Pendidikan Universitas Syiah Kuala.," pp. 52-62, 2014.

[9] I. Smarabawa, I. Arnyana, \& I. Setiawan, "Pengaruh Model Pembelajaran Sains Teknologi Masyarakat terhadap Pemahaman Konsep Biologi dan Keterampilan Berpikir Kreatif Siswa SMA," e-Journal Program Pascasarjana Universitas Pendidikan Ganesha, vol. 3, pp. 1-28, 2013.

[10] J. L. Anderson, J. P. Ellis, \& A. M. Jones, "Understanding Early Elementary Children's Conceptual Knowledge of Plant Structure and Function through Drawings," CBE - Life Sciences Education, vol. 13, pp. 375-386, 2014.

[11] M. O. Bekkink, A. R. Donders, J. G. Kooloos, R. M. de Waal, \& D. J. Ruiter, "Uncovering Students' Misconceptions by Assessment of Their Written Questions," BMC Medical Education, vol. 16, pp. 1-7, 2016.

[12]S. Siregar, "Pengaruh Model Pembelajaran Inkuiri Berbasis Media Animasi terhadap Pemahaman Konsep, Sikap Ilmiah, dan Assesmen Kinerja Siswa pada Konsep Sintesis Protein," Jurnal EduBio Tropika, vol. 1, pp. 60100, 2013.

[13] A. Abdi, "The Effect of Inquiry-based Learning Method on Students' Academic Achievement in Science Course," Universal Journal of Educational Research, vol. 2, pp. 37-41, 2014.

[14] W. A. Sandoval \& B. J. Reiser, "ExplanationDriven Inquiry: Integrating Conceptual and Epistemic Scaffolds for Scientific Inquiry," Science Education, vol. 88, pp. 342-375, 2004.

[15]C. Scott, T. Tomasek, \& C. E. Matthews, "Thinking Like a Scientist!" Science and Children, pp. 38-42. 2010.

[16]E. Tafoya, D. Sunal, \& P. Knecht, “Assessing Inquiry Potential: A Tool For Curriculum Decision Makers. School," Science and Mathematics, vol. 80, pp. 43-48, 1980. 
